\title{
Placing Joseph Banks in the North Pacific
}

\author{
Daniel Clayton \\ School of Geography and Sustainable Development \\ University of St Andrews \\ dwc3@st-andrews.ac.uk
}

Dan Clayton is a Senior Lecturer in Geography at the University of St Andrews. He has long worked on contact and colonialism in the North Pacific, and on the relations between geography and empire.

The primary fact of the Modern Age was not that the earth goes around the sun, but that money goes around the earth

Peter Sloterdijk, In the world interior of capital, 46

\begin{abstract}
The South Pacific was a fulcrum of Joseph Banks' maritime world and global networks. The North Pacific was a distance and intangible fringe. This paper is concerned with how Banks should be 'placed' in the North Pacific. It tracks how Banks's activities have been delineated in terms of languages and categories of global and local, and centre and margin, and then considers the historical and geographical specifics apposite to his connection to the North Pacific. In this setting, ideas of place (as location and assignment) and capital (as a circulatory and everyday practice of exchange and opportunism) come into view and question the distinction between science and commerce in Banks historiography. The paper considers a diverse group of non-native figures - explorers, traders, cartographers, scientists, collectors - operating in the North Pacific in the 1780s and 1790s whose initiatives and missives passed across Banks's desk, and assesses their place in Banks's archive by drawing on Peter Sloterdijk's ideas about the interiorising and exteriorising logic of capital.
\end{abstract}




\section{Introduction}

This paper in this issue exploring new perspectives on Banks considers how he might be placed in the North Pacific - the vast coastal and oceanic area stretching from Mexico to Alaska, across to Japan and down to Canton, and including the Hawai'ian Islands. How was Banks connected to this part of the world? How was it made by its connection to Banks, and how did it impinge upon the nature of that connection? What are the primary facts and specifics in this case? Consideration of these details and this situation is wrapped around a more general concern with the language and categories of local and global, and centre and margin, used to situate Banks in different kinds of histories and geographies. The paper recalls some of the pleas and missives pertaining to this region that passed across Banks's desk in Soho Square and through his webs of correspondence and patronage in order to pose larger questions about what is gained and what is lost when Banks is made a focal point of historical attention, and about the ability of distant or 'extraneous' places and agents to represent themselves, and how figures like Banks might or should have in 'their' histories.

The most palpable connection that Banks had to the North Pacific was via a range of encounters between Native people along the coast and a diverse group of newcomers explorers, traders, cartographers, scientists and collectors, chiefly from American, British and Spanish backgrounds. The South Pacific was a fulcrum of his attention and expertise. The North Pacific was a distant fringe. But it was a fringe with a fabled locale, Nootka Sound, and one which continues to flicker in the public imagination as well as endure as a magnetic exemplar in historical debates about the remit of Native, global. oceanic and postcolonial history, world-systems research, and most recently microhistory. ${ }^{1}$ Nootka Sound remains what Matt Matsuda has neatly termed "a 'local place' with a global resonance." ${ }^{2}$ The paper deploys hitherto underexplored ideas place and capital -- or, more precisely, assignment (placement) and what, following Peter Sloterdijk, shall be described as the interiorising logic of capital -- to mould understanding of how Banks might be placed in the North Pacific. ${ }^{3}$ It will be argued that in this situation the primary fact of money going around the earth has more truck than planetary knowledge circulating through science (captured in the epigraph). 
An overview of the regional, historiographical and theoretical contexts from which these lines of enquiry are hewn is followed by a foray into the North Pacific edges of Banks's networks and understanding, and how he might be placed there via the circulatory -expanding, competitive, fluid, profit-driven and mendacious -- filaments of capital, and, accordingly pulled away from a language of networks and scale, and centre and margin, which more readily permeates Banks scholarship.

\section{Banks and the Northwest Coast}

The North Pacific did not begin to be drawn into Western horizons of knowledge and power until the 1770s, first of all when Spain sent explorers north from San Blas, Mexico, in search of the fabled Northwest Passage (the fabled high latitude waterway connecting the Atlantic and Pacific) and to lay claim to new lands to rejuvenate the fortunes of its beleaguered New World empire, and more decisively in the spring of 1778, when Britain's feted navigator James Cook, then on his third voyage to the Pacific and also looking for this legendary short cut from Europe to China, anchored for a month at Nootka Sound (which he initially named King George's Sound) among Nuuchah-nulth people, exchanging an assortment of metal, fabric and porcelain wares for food, access to timber, and for sea otters pelts, for which Cook's crews found a ready market in Kamchatka and Canton. Cook's reconnaissance yielded a sparse coastal Chart of the N.W. Coast of America, with the continental interior depicted as an enticing blank, and the region was known thereafter to British and American mariners as the Northwest Coast of America (Northwest Coast for short). ${ }^{4}$

Within seven years trading ships fitted out initially by London- and Indian-based merchants, and with officers and crew from Cook's voyages involved, were beginning to flock to the coast, principally at first to Nootka Sound, with a Native population of over two thousand when Cook visited, to trade for sea otter pelts which could be sold to Chinese merchants in Canton and Macao for a handsome profit. What quickly became known as the "North West coast trade" was lucrative. Merchants solicited Bank's patronage in order to attract investors and with a view to protecting their new-fangled enterprises from the monopolistic restrictions on trade and the movement of goods in Asia and Pacific bound up with charters of the English East India Company and South Sea Company, restrictions that were tightened in 1780 . The first merchant to enter the 
sea otter trade, Henry Cox, got into it because the East India Company had let him sell his deceased father's stock of clocks in Canton, and others quickly followed, petitioning the Company through Banks for a similar relaxation in restrictions, although some took matters into their own hands by sailing under the flags of other countries (Austria, Portugal, and Sweden). ${ }^{5}$

American merchants, mainly from Boston, quickly followed and soon dominated the trade. And as Frederic Howay wrote of the trade's American side, and alluding to its alchemistic qualities, "The Americans had a perfect golden round of profits: first, the profit on the original cargo of trading goods when exchanged for furs; second, the profit when the furs were transmuted into Chinese goods; and, third, the profit on those goods when they reached America." However, it transpired that investors and those who came to Native shores were overly opportunistic about both the straightforwardness and longevity of this route to profit, on account of stiff competition between trading vessels, a dramatic depletion in the sea otter population, the decimation of Native populations due to the influx of disease (smallpox, measles and influenza) and rise in conflict between Native groups, the financial and practical difficulties of fitting out voyages that would not see a return on investment or lines of credit for eighteen months to two years, and not least the trading acumen of Native groups, who incorporated traders and their wares (and after not long, guns, powder and alcohol) into their own societal and geo-political dynamics. Such writing was on the wall by the summer of 1792, when the American Robert Haswell pondered the absence of Native people while anchored at Port Banks (Figure 1), a hitherto prized trading destination so named by George Dixon in June 1787 "In honour of Sir Joseph Banks". ${ }^{7}$

\section{[Figure 1]}

Figure 1, Port Banks. Drawn by Robert Haswell. F.W. Howay, ed., Voyages of the Columbia to the Northwest Coast 1787-1790 and 1790-1793 (Portland: Oregon Historical Society Press, 1990), 345

Still, one of the first London merchants on the scene, Richard Cadman Etches (about whom more later), secured Banks's support, formed the King George's Sound Company, and despatched the ships the Prince of Wales and Princess Royal under the command of James Colnett (who had sailed on Cook's second voyage) to the Northwest Coast with a syndicated company subscription (he claimed to Banks) of two hundred thousand 
pounds and the grand plan of not only developing a sea otter trade but also establishing a permanent British settlement at Nootka Sound. ${ }^{8}$ He estimated that in Canton a "prime sea otter" fetched sixty-five Spanish dollars (upon which Etches bestowed an exchange rate of five shillings and four pence, then nearly two days wage for a skilled tradesman, or around twenty pounds in today's money). He valued "prime otter cloaks" (customary Native garb) at one hundred and fifty Spanish dollars (or fifty pounds today), and calculated that his overall trip around the North Pacific, at heart of which lay the movement and sale of over two thousand furs, yielded a gross return of over twenty thousand pounds (over one million five hundred thousand pounds today). ${ }^{9}$ Such calculations were often exaggerations (hyperbole was part and parcel of the trade), although as James Gibson surmises, "During the 1790s an average of $\$ 62,673$ worth of American trade goods were bartered on the coast for furs annually... [and] the annual value of American shipments of sea otter skins to Canton averaged some $\$ 350,000$." 10

Through Etches and others the Northwest Coast became hooked up to an array of private, chartered and government trading ventures and networks spanning Britain, Europe, Asia, the Pacific, and North America, and revolving around the movement and exchange of an array of commodities -- cotton, diamonds, furs, glass, iron, opium, plants, porcelain, teas, textiles, silk, spices, victuals, and wood. This absorption of the Northwest Coast into an expanding and shifting capitalist world system also happened at a time when the relations between what Karl Marx later identified as the "two forms" of "merchant's or trading capital", "commercial capital and money-dealing capital" were opaque, geographically diffuse, and arched across the affairs of government and business. ${ }^{11}$

Alexander Walker was another of the first maritime sea otter traders to appear at Nootka Sound in the wake of Cook, in the summer of 1786. He discovered a medal hanging around a child's neck that "bore the name of Joseph Banks Esqr." and later added that the Native chief of the sound, Maquinna, "was the only Person, in whose Possession we saw any thing, that had belonged to Captain Cook. He had a long narrow piece of brass with Joseph Banks Esqr. Engraved on it, several fine Copper bracelets; and some Queens ware Cups and Saucers, which he said he had got from that celebrated navigator." 12 Walker's boss, James Strange, operating on Banks's advice, and travelling (as some merchants did, as a 'supercargo') on the unconvincing pretence that he undertaking a 
"scientific expedition" rather than "commercial voyage," observed that the Native people he encountered were astute traders but inveterate thieves and that avoidance of conflict "was more Owing to the caution I took... rather than to any Good disposition in them". ${ }^{13}$

As David Mackay notes, "Dozens of other supplicants petitioned Banks in similar ways, often with the customary homage to Cook, or perhaps Linnaeus - generally with obeisance to the deity of empirical science" (which included chronicling one's discoveries). ${ }^{14}$ Science and commerce were riven by the eighteenth-century politics of politeness, and with science lauded as the more estimable category of human ambition and mode of contact with Native groups, albeit one that it was impossible to fully expedite without the glories and riches that could be bestowed on the individual and society through commerce. ${ }^{15}$ One buccaneering trader, John Meares, with oblique connections to Banks and no ostensible need to flag the scientific intent or worth of his endeavours, declared: "We had not the time, even if we had possessed the ability, to have pursued the track of the philosopher and the naturalist. We had other objects before us". ${ }^{16}$ But those whose presence was freighted, however circuitously, through Banks and his connections, felt the impress of propriety, while blurring (often unwittingly) the lines of distinction it performed: "all Nations improve by commerce which I have every reason to believe with soon to be extended to Corea and Japon where a great call for furs will happen", Colnett ventured. ${ }^{17}$

At the height of this sea fur trade, in the 1790s, up to twenty ships were visiting Nootka Sound and other Native villages each year and by then the region had been incorporated into what Paul Mapp describes as "the elusive west" and a "competitive, territorially insecure, diplomatically unstable, and conflict-ridden international system." 18 British traders and Spanish officials stationed at Nootka Sound came to blows in 1790 (and with both Colnett and Meares in the thick of it), precipitating a diplomatic crisis between the two countries over territorial sovereignty in the Pacific that almost culminated in war. George Vancouver was subsequently sent to the region to undertake a systematic survey of the coast for the British as well as to visit Nootka Sound to receive property and buildings there that Meares claimed had been confiscated by the Spanish. ${ }^{19}$ The Spanish also undertook their own systematic survey, and an imperial battle of maps commenced..$^{20}$ American traders on the scene too, not only witnessing the British- 
Spanish conflagration at Nootka Sound but also setting a precedent with their own maps and journals of their activities for future political wrangling between Britain and the United States of America over territorial sovereignty which was not resolved until the Oregon Treaty of 1946 established the forty-ninth parallel from the Great Lakes to the mainland Pacific coast as the international border and presaged the arrival of American and British settlers.

By the time Banks died, in 1820, stocks of sea otters and other fur-bearing animals were largely spent on the Northwest Coast, and one of the last traders to chronicle Native life at Nootka Sound, John Jewitt, did so as a captive (after his ship, the Boston, had been blown up by Maquinna) and began his Narrative of the Adventures and Sufferings (first published in 1815) by recalling his happy school years and apprenticeship with a surgeon "at Reasby in the neighbourhood of the celebrated Sir Joseph Banks." ${ }^{21}$ Banks never visited the Northwest Coast, only glimpsed the beginnings and edges of the sea otter trade, and was in no position to foretell a colonial future for the region. ${ }^{22}$ But as these snippets suggest, he was a common reference point, and brought a chain of connections to science, commerce and empire with him.

\section{Banks's global and provincial 'turns'}

How might this traffic be situated in wider Banks scholarship and debate? In a recent paper on Banks's "provincial turn" Julian Hoppit rehearses how the "global turn" in historical inquiry of the last few decades has rejuvenated interest in histories of exploration, science and trade, and revitalised interest in figures such as Banks, whose commercial and scientific interests spanned the globe, and whose curiosity and patronage helped to make projects of collection, classification, cultivation and curation central to the economics and culture of empire. ${ }^{23}$ Hoppit traces how, in a wider sense, "local, regional and national" histories have been reconceived in more expansive and relational terms, with a more explicit concern with global comparison and connection, and with a greater sensitivity to the modes and hierarchies of power and representation linking far-flung places and phenomena. It is not the case, Hoppit avers, that all history now is, or should seek to be, global (or world) history in design, scope or content. But across a range of fields and specialisms there is a now heightened awareness of the way hitherto circumscribed or inward-looking histories have side-lined dynamic forces 
operating outside their immediate realm or remit, and side-lined or underestimated how this 'outside' has helped to constitute the 'inside' (the nation, region, dominant culture, or historiographical paradigm).

This global turn has both been shaped by, and helped to shape understanding of, contemporary processes of globalisation, by which is meant, broadly, the increasing interconnectedness of disparate planetary processes, and the disciplinary project of postcolonialism, which challenges the deep-rooted Eurocentrism in historical writing and seeks to make way for 'other' voices, regions and perspectives. These two developments have spawned a complex politics of location. If significant elements of how late eighteenth-century capitalism, empire and science worked crossed Banks's desk in the form of correspondence and petitions for patronage from scattered adventurers and opportunists, then the distant peoples, places and projects involved should not be treated as subordinate to a pre-existing and generative hub of agency residing with Banks. These settings matter, and not least to those whose lives and fortunes were touched by Banks networks and resourcefulness. So, from where, and on whose terms, should a figure like Banks now be placed in the array of histories of which he was part? Might his money, influence and connections now be deemed more, or less, relevant, innocent, felicitous, fateful, ragged or deleterious than before? One might zoom in on distant contexts, a la the highly localised detailed studies of microhistory, in order to make Banks a less-than-global player. But how and at what point in this recourse to the far-away does or should Banks get effaced as a common reference point?

Hoppit alights on how, within these global and postcolonial turns, Banks has been reconfigured as an 'agent of empire' but suggests that for all of his "extensive global preoccupations" and sense of himself as a "citizen of the world" (stemming from his participation in James Cook's first voyage to the Pacific), in later life he became more concerned with matters closer to home, and particularly with his Lincolnshire estate near Reasby (and engrossed in sheep and wool correspondence more than that over Indian and Pacific trade). ${ }^{24}$ Hoppit suggests that recent literature exaggerates Banks's global connections "bypassing the national frame" and downplays his "provincial turn". ${ }^{25}$ But there is a parallel danger here, and of which Hoppit aware: that in seeking to recover the 'provincial', a hoary and myopic provincialism of yesteryear, which was symptomatic of Britain's sense of its own global self-importance, might re-enter the frame. ${ }^{26}$ Hoppit thus 
raises important questions about the relative weight that should be accorded to 'the local' and 'the global' in Banks's affairs and archive, and the effects of doing so at a time of wider debate about how to 'play with scales'. ${ }^{27}$

\section{Questions of scale and space}

Geographers insist that scales are neither fixed nor given but are socially constructed and contested, and involve relationships of connection, separation, delimitation, and often ambiguity. And beneath the architectonics of scale lays analytical building blocks of place and space (location, position, distance, difference, linkage, and division) and question of how and why some places and 'spaces of knowledge' matter more than others? Recent research on Banks and eighteenth- and nineteenth-century science and empire is sensitised, somewhat, to this spatial way of thinking and probes the myriad sites and spaces - botanical gardens, counting houses, forts, herbaria, museums, ports, and ships- within and through which ideas, information and influence were produced, housed and disseminated, and the technologies of travel and representation - the book, catalogue, exhibit, gun, map, journal, navigational aid - that were involved in the construction of the 'scale' of his operations. Such rudiments in how science and empire were 'put in place' and stretched over space were pivotal to what counted as credible and reliable knowledge. ${ }^{28}$

One of the chief ways in which Banks has been re-read in this regard is as a "centre of calculation". This expression is deployed by David Philip Miller (and drawn from the French philosopher Bruno Latour) as a shorthand for how science and empire were not simply entangled in Banks's undertakings but also had a spatial shape and direction. The myriad collections, contacts, itineraries, schemes and texts in Banks's world moved or trended towards a centre, where some order, valuation and durability of meaning was placed on their otherwise irresolute diversity. For reasons that shall be unpacked presently, this expression, and the language of centre and margin (and related tropes of distance and difference, absorption and diversion, and order and commotion) from which it arises do not quite fit the North Pacific story explored here. But nor, quite, does a variant of this story being told in emerging scholarship that has been made possible by the laudable collation and publication of previously scattered and buried Banks material: "that, while Banks undoubtedly presided over numerous influential institutions, he was 
less a global agent with an imperial agenda for science than an expert facilitator or connector, whose access to a multitude of communities interested in his patronage, connections and knowledge enabled him to recommend collaborators and supporters for a great diversity of projects." ${ }^{29}$ In this case, the idiom of centre and margin is not supplanted so much as discharged for other duties, with the centre no longer holding, ordering, or calculating so much as before. However, there is a propensity (and perhaps danger) here that the question of from where knowledge is evaluated, and with what effects of power, becomes indeterminate.

\section{The world interior of capital}

Banks scholarship has thus furnished fertile ground for debate about how and whether it is possible have a 'balanced' interest in, or 'work between', global and local contexts and scales, and centres and margins. The view to be developed now is that it is also important to address issues of assignment - how meaning is centred or dispersed - and circulation - the routes that knowledge and power take in the process becoming located and connected. The historian of science Nicolaas Rupke uses the term "assignment" to talk about questions of site and placement in nineteenth-century science, and highlights the agency of the historian: "We do not merely happen to find nineteenth-century science in certain locations", he writes; "we assign science to locations that are selected and constructed by us, not just reconstructed, to validate our purposes by conflating them with science." ${ }^{30}$ Rupke reflects in this vein upon various sites of nineteenth-century science -- hothouses, experimental stations, ships as floating herbaria, laboratories, and learned societies -- and the practices and instruments - of witnessing, collecting, mapping, classifying, preserving, drawing, writing -- associated with them.

Banks belongs here, and both assigned science and commerce to certain sites and spaces of knowledge pertaining to the North Pacific and had them brought to his attention by others. In the North Pacific the operations of merchant capital, and the projects and processes of scientific exploration and geo-political aggrandisement taking place in their midst, were an essential part of the question of assignment, and they revolved around what Edward Said, in a wider register, described as a potent and often combustible mix of "precise detail and imperial vagueness". ${ }^{31}$ 
Profit, and the prospect of attaining it through Banks's patronage, pitted speculation against evidence. Profit needed to be assigned - pinpointed, located, with figures and calculations, on maps and with observations meticulously recorded in journals and ledgers. But it also worked by rumour and hearsay, and via a twofold clash of values. First, commerce was about both advantage and advancement: both aggressive competition (profiteering) and the civility and social mobility to be accrued from generating wealth. Second, in the process of expediting this mixed and split value overseas -- which Marx encapsulated in the idea of capital as value in motion wrapped up with restless desire -- competition was sublimated to civility and shone as capitalist decadence. And as Marx continued, it shone in the name of a law. Mercantile capital's double-headed games of chance -- speculation and risk, credit and debt - worked by a decree that was (is) in some ways contrary to "the concept of value" as an exchange of equivalents: namely, "To buy cheap and sell dear is the law of trade." 32 For, eo ipsos did Western traders, Native people, or Banks see 'cheap' or 'dear' in the same way, or get a steady fix on what constituted these measures of value and exchange as plans and objects got moved around the earth? The frayed and restless lines between civility (truth and decorum) and competition (cunning and barbarism) that ran through the North Pacific as a 'traffic' in furs were most neatly expressed by the American merchant Sullivan Dorr in 1798, who wrote of the Native people he encountered: "these cunning savages... are great Merchant traders." 33 The Western expectation that Native people would not grasp the 'true' value of their resources and wares -- or know how to buy cheap or sell dear -fell flat, and Dorr knew that traders's frustrations frequently spilled over into violence.

Sloterdijk's musings about the "world interior of capital" are suggestive in this regard. He re-thinks how, beginning with the earliest European circumnavigations of the globe, the earth became internal to capital through its ever-expanding reach, and to the extent that the boundaries of this interior - i.e. a world imaginable without capital -- became undiscernible. However, it is still important, he continues, to learn how this world interior of capital came to be by immunising itself, through its commodity spectacles, from an exterior world of plunder, war, slavery, genocide, disease and misery upon which it was expedited. ${ }^{34}$ Sloterdijk reads the creation of the world interior of capital as the jagged and unequal history of globalisation, and in so doing supplants imperial and postcolonial categories of centre and margin, travel and return, and taxonomy and turmoil, with a more motile language of interiors and exteriors, circulation and 
exchange, and transmission and restlessness. He names the grand glasshouses of Britain and France, and especially the Crystal Palace, as the historic location and place metaphor for this interior, describing these sites of experimentation, commodification and imperial display as "cult container[s] in which humans pay homage to the demons of the west: the power of money and pure movement". ${ }^{35}$

The collection and movement of the world's plant, animal, mineral and human resources, which was pivotal to the late eighteenth- and nineteenth-century coupling of science and empire, was part and parcel of what Sloterdijk describes as the "transformation of all outside conditions into observations, and all observations into announcements... [concerning] subjects who will write what they have seen or found." 36 Moreover, this transformation is based on a principle of "competition" and make places coveted theatres of dreams and ambitions. It is in this motile and circulatory way, rather than in terms of the more static idea of 'centres of calculation', that James King's often cited remark from 1780, that Banks was "the common centre of we discoverers", might be brought into view ${ }^{37}$ The details of how Banks became placed in the North Pacific might be cathected to this other story about the world interior of capital.

Banks' connection to events five thousand and more miles away from Soho Square emanated from his association with Cook and a number of his crew, his friendships with Lord Sandwich and Lord Mulgrave, and a set of convoluted connections, through these and other individuals, to different state organs (especially the Admiralty, Board of Trade, Foreign Office and Home Office), an international world of science and collecting that revolved around his premiership of the Royal Society, and a late eighteenth-century British imperial world that juxtaposed the dawdling and unwieldy levers of the state and the twitchy and profit-sensitive perturbations of merchant capital in an age of revolution. ${ }^{38}$

It is possible to discern, through this web of connections, three assignments, or modes of placement, each with their own logic, drama and genealogy: Enlightenment science, capitalist expansion, and the imperial rivalries in what James Fichter and Paul Mapp have described as a volatile eighteenth-century international system that was shot through with difficulties in communication and circulation across spaces and cultures. ${ }^{39}$ Much of the literature on the Pacific, as well as much postcolonial theory, nominalises 
these modes as distinct, in order then to register their duplicities, particularly by saying that scientific travel -- navigating, botanising, mapping, and observing 'exotic' peoples -could not and did not live up to its Enlightenment pretensions of objectivity and civility. Sloterdijk avers that between 1789 and 1968, which he characterises as an age of "ideologues", "'history', alongside 'nature', was viewed for a time as the highest client of action, [and] invocation of its assignments held the greatest disinhibiting value." 40 Interpretation of, and insistence upon, this passage from purity to duplicity ensued apace after 1968, Sloterdijk continues, and he parodies the new age of "consultants" it fomented. But what if this passage - interpretation -- was resisted and science, commerce and empire were assigned to the North Pacific as different faces of Pacific interiors and exteriors of capital, and, as Sloterdijk notes, with "experiential knowledge" from the remotest corners of the globe acquiring a new "cognitive value-form"? ${ }^{41}$ What if Dorr's observation about Native traders points to just one inferno rather than to the purity of one (science and civility) sullied by but fenced off from another (commerce and cunning)?

Inklings of this idea might be gleaned through a foray into Banks's two chief points of connection with the North Pacific: Etches, the Derby merchant who drew him into sea otter trade; and Archibald Menzies, the surgeon-cum-naturalist whom Banks placed on Vancouver's expedition but who had started out in the sea otter trade.

\section{Menzies and Etches}

It is instructive to begin with Menzies. Banks was entrusted by a talented young strategist of the Home Office, Evan Nepean, to draft Menzies's instructions in connection with Vancouver's government-sanctioned expedition, and, with Alexander Dalrymple, to draft Vancouver's surveying instructions. Both were among the longest and most detailed sets of instructions ever written for a European voyage of scientific discovery, and they point, I think, to how Banks was implicated in the world interior of capital. ${ }^{42}$ "The business on which you are employed" is of an "extensive nature", Banks wrote to Menzies; and "the utmost degree of diligence and perseverance on your part will be necessary to enable you to do justice to your Employers and gain credit to yourself." Along with matters of natural history and geography, Menzies was to consider "the productions, the probable Climate, and whether, should it an time 
hereafter be deemed expedient, to send out Settlers from England... [and ascertain where] the Grains, Pulse and Fruits cultivated in Europe are likely to thrive." When it came to Native people, he was to "enumerate" everything that was "new or particularly curious", including "every part of the natural History of the Sea Otter", and if anything "should appear to you so unreasonable as not to be likely to meet with Credit when related in Europe, you are, if you can do it with safety and propriety, to make yourself and eyewitness of it, in order that the fact of its existence may be established on as firm a basis as the nature of the Enquiry will permit." 43

Menzies wrote to Banks prior to receiving these instructions with a long list of "such articles as I think will answer best for Trading on the West-coast of N. America." ${ }^{44} \mathrm{On}$ both counts, and in a good deal more of this correspondence between Banks and Menzies, the transformation of curiosity into curiosities was freighted by the cognitive value-form of capital, and particularly an envisioning of capital as a two-headed estimation of economic and social value and advantage -- by a language of newness, credit, employment and production. Sloterdijk writes: "It is typical of the Modern Age habitus of acquiring, bringing, contributing, collaborating, going forwards and systematising that the principal research takes place in the form of competitions" competition over personal and collective enrichment, honour, truth, and the eyewitnessing of newness as the fount of the new opportunities for trade. ${ }^{45}$ And indeed, competition for Banks' attention. While Menzies wrote lengthy and detailed letters to his patron, one senses that he was never quite sure about what Banks had received, or whether the effort to do himself 'credit' had altogether been worthwhile. Menzies (like William Bligh) got considerably less back from Banks.

Menzies's flawed wish-image, perhaps, was of all knowledge of the "new and particularly curious" being incorporated into what Sloterdijk characterises as a "fantastic integral book - a book of cognitive records" holding together a whole history of the "solitudes" and "lonely successes outside" undertaken by the "bringer-back of experience." Solitude became an integral part of Menzies's undertaking, particularly on Vancouver's voyage (neither he nor Banks got on with Vancouver), but also, and upon Banks's recommendation, on his prior commercial voyage to the Northwest Coast in 1786 as surgeon on Etches's ship the Prince of Wales. 
Responding to Banks's instruction to record every part of the Natural history of the sea otter, Menzies produced a paper that was read before the Royal Society in 1796, where it was noted that "The long hairs shine with a brilliant gloss, but the short fur is exceedingly fine, soft and thick set." 46 The allusion created by the full stop at the end of Menzies's sentence -- the polish and lustre of the furs by which science was advanced and distant profits were realised as luxury items, either directly, in the form of hats and garments and blubber of the animal used as lamp oil, or indirectly, in the guise of porcelains, silks, and so forth, traded for the furs -- is to the world interior of capital. Menzies refers to the drawing of the sea otter made by Cook's artist John Webber but says nothing in the paper about the sea otter trade. The full stop disguises an undercoat of profiteering that is kept it at a distance yet integral to the capital benefits of science.

Etches promised Banks that he would grant Menzies "ample latitude in his pursuits" and hoped that his surgeon-scientist would "confess having experienced that liberality which your recommendation Sir most certainly demands from me". And it was through his association with Etches that Menzies grasped how the desire to turn the world to one's credit applied to merchants, and why they refracted it through Banks. ${ }^{47}$ Entrepreneurs, and sailors-turned-traders, used Banks as a go-between and decoy for their punditry and speculation. Banks became a flashpoint in the pursuit of gain and notoriety, and his connection to Etches and the gang of adventurers who gathered around him was key to how his connection to the North Pacific took shape.

\section{[Figure 2]}

Figure 2. John Webber, A sea otter, 1778. From: Captain James Cook (and Captain James King), $A$ voyage to the Pacific Ocean. London: G. Nicol and T. Caddell, 1784, atlas, plate 43.

Etches appealed to Banks to approach the Company, and Banks put him on to veterans of Cook's third voyage, Naniel Portlock and George Dixon, as possible captains.

Would it be stretching it to suggest that Banks was swept along by a prospecting vision that was essentially commercial rather than scientific or imperial? Again, the impulse to put these visions into separate boxes hides as much as it reveals about the cognitive value-forms involved in the North Pacific. Even so, it was arguably neither the fabled Northwest Passage of scientific and imperial lore that lay at the heart of Banks's 
approach to the North Pacific as it was expedited through his connection to Etches, nor the prospect simply of incorporating new flora, fauna, human artefacts and ethnographic wisdom into his taxonomic field. Rather, it was the prospect of developing a trade with Japan, which was a "long wish'd for object" of his, and one put in his head partly, in 1777, by the Swedish botanist Carl Thunberg, and later (this phrase) by King. ${ }^{48}$ Banks linked the sea otter trade to the opening of a market in Japan and the establishment of a permanent British settlement at Botany Bay. Etches stoked Banks' geographical imagination by adding the thought of establishing permanent British at Nootka Sound.

Banks soon stood back from this commercial outreach, but not before becoming further embroiled with Etches and witnessing a media war in London between traders and pundits -- involving Etches and Dixon, and more particularly their associates, Colnett and Meares, and armchair experts such a Bland Burges and Dalrymple -- over the events that had precipitated the Nootka Crisis of 1790. As both Marx and Smith opined, while capital can be patriotic, it is also the most unpatriotic of vessels, stretching beyond national boundaries and eroding sovereignties.

In appealing to Banks, British merchants drew a connection between private "worthiness" and national "interest" that juxtaposed Banks's patrician view of nature and commerce as a landed estate, to be extended, improved and managed in an orderly fashion, with a rather different vision of the maritime world as a decadent, risky, opportunistic and mutinous realm of economic experimentation and social discord. Etches's language in his letters and petitions to Banks was one of "system" and "advantage," "experience" and "utility," "exertion" and "perseverance", "value" and the value in "trafficking," "sociability" and "banditry", and he called upon Banks to promote "government" and "regulation", provide "support" and "protection", and prevent "anarchy" and "confusion." 49 Etches's intimations were complex, and few traces of what he might have got back from Banks survive. Etches's 'anarchy' and 'confusion' centred on the difficulties of trading with what (like Dorr) he referred to as a "cunning" Native population on a "savage coast", but also on aggressive competition between British and American traders and their own cunning in a traffic that became a competitive trade in lies, deception and subterfuge. Once more holding Banks up as the keeper of that fantastic integral book, Etches opined in May 1792: 
I am fully persuaded that you, Sir, will admit that the Annals of History have not on record, so many important discoveries and stupendous Commercial Advantages being achieved to the Nation by the Enterprize and at the expence of Individual Merchants; few of the numerous streams and Channels opened up by us for the Expectation of the Manufactures of England - and Importation of American and Asiatic products - are as yet known but by ourselves.

In fact, a good many of these 'channels' and 'expectations' had already been brought into the world interior of capital, and the connection between interior and exterior for Etches, as it was, albeit with a different face, for Banks, was through the relations between discovery and advantage, and a language of credit, debt, expense, reward, and interest.

The Native people of the Northwest Coast sought to take advantage of the newcomers who came to their shores and did so by controlling the supply of furs and access to ships. The sea otter trade concentrated power in the hands of specific chiefs -- Maquinna of Nootka Sound and Wickanninish of Clayoquot Sound to the south being the best known on the west coast of Vancouver Island -- but also spawned Native competition, war, slavery, and profound social, territorial, demographic and ecological change in Native communities. Not the most auspicious of circumstances, Anya Zilberstein has recently reflected, in which to cement "the project of creating a definitive, encyclopaedic knowledge of the world through physical collections." ${ }^{50}$ An increasingly interconnected world of collecting, trading and "translocal relationships" did not simply foster the proliferation of cultural forms and meanings; it also "accelerated environmental and social changes that ultimately eroded the basis of those connections." 51

If Banks's interest in the North Pacific was fleeting and tentative, it was partly because by as early 1788 he had grasped, chiefly from Portlock and Dixon, that the sea otter trade not likely to be nearly as profitable or permanent as was hoped. ${ }^{52}$ In 1785 James Hanna reportedly traded six hundred furs at Nootka Sound in just a few days. By 1803, when Jewitt was taken captive, Native groups were trying to come to terms with the rapid flight of capital from their shores. Banks knew that the opportunism, risk of financial ruin, and the potential for what were often called "depredations" (theft, hostage-taking, gun violence) associated with the sea otter trade called for trusted 
geographical knowledge, navigational and cartographic skill, and discipline at sea and on distant shores. Such basic requirements might be considered banalities of power in this context. In the North Pacific they fostered an economy of distrust and deception that made geographical information and ethnographic observation far from definitive or easily combinable in some far-off centre of calculation. Menzies struck this chord in a letter to Banks the moment he arrived at the entrance of the Strait of Juan de Fuca (southern tip of Vancouver Island) in 1792 and got conflicting messages about whether or not he was looking at the entrance to the fabled Northwest Passage. ${ }^{53}$ He didn't know what or who to believe - American traders, British traders, the Spanish, and different individuals from these different constituencies vying for his ear. He hoped to return to see for himself.

Meares was the most celebrated and accomplished of liars. His Memorial to the British Crown about his 'purchase' of land from Maquinna at Nootka and erection of a dwelling there, and the subsequent arrest of his associate Colnett and seizure of his property, lies at the heart of a body of tendentious knowledge over which historians, myself included, have spilled considerable ink. Maquinna referred to the captain of the Feliz Aventureia as 'Liar-Liar Meares' (Aita-Aita Meares) ${ }^{54}$ Nootka Sound is still this local place with global provenance, and still represented on Western terms -- for example in the BBC's recent period drama Taboo, with the rogue adventurer James Delaney claiming to own land bought by his father from the chief of Nootka Sound, and with the "East India", and British and American governments, coveting it too. In the last episode Delaney's ship, the Felice Adventurero, gets blown up by the East India.

\section{Conclusion}

John Gascoigne rightly suggests that Banks's "map of knowledge" stressed the "interrelated character of all knowledge and its need to be exposed to public scrutiny," and that all knowledge "could be brought into a methodically ordered synthesis." ${ }^{55}$ This paper has suggested that the circumstances in which Banks was placed in the North Pacific tested this map of knowledge. This part of the world was made accessible according to the ideal of Banks's map but the mechanism driving and ordering the region's legibility was brute competition and duplicity, which undermined the basis of this very order. Wherever they went in the Pacific, the likes of Menzies and Bligh 
dutifully and fastidiously reported to Banks on the movement of ships and the shipment of goods and objects, sometimes in an anodyne way, sometimes with a sense of intrigue, but rarely, if ever, with a sense that what they observed and jotted down might eventually all be placed on some orderly or large scale map of knowledge that might match Banks' ideals, plans and strategies. This frustration comes to the fore in some of their correspondence with Banks.

To this day a potent image of Banks as a presider prevails. For example, James Secord notes: "Commanding a vast correspondence with everyone from prime ministers to commercial gardeners, he could speak as authoritatively about the cultivation of potatoes as about national trade policy." ${ }^{56}$ Similarly, James Ronda observes: while Cook was "the media star, the darling of the age... Banks was the planner, the strategist, the powerful intelligence that linked Enlightenment philosophies to dreams of empire, and the more mundane concerns of ships, sailors, and uncharted waters." 57 The image projected by this paper, which has sought to delineate those facets of Banks's sprawling commercial and scientific interests and networks that come into view when they are viewed from their North Pacific fringes, is of Joseph Banks as an "assemblage" (a term that crops up quite often in his correspondence): as a sender and receiver of letters, instructions, ideas, excitements, and testimony helping to spin, and whirling within, what has been described (following Sloterdijk) as the world interior to capital (of a commodity world of credit, gain and mendancity), rather than as a master and commander of a network. ${ }^{58}$ Sloterdijk sees the "nautical ecstasy" of the modern age (the desire to get up and go bound up with the profit-twitchy perturbations of capitalist 'advancement' and uprooting) as the traffic of this interior and assemblage: "What we here term restlessness... encompasses entrepreneurial spirit, frustration, vague expectation and criminal uprooting without any distinctions between them. The unrest of money mingles with the unrest of 'uprooted existences'... The European dream of a good and better life is caught up in the maelstrom of a totally other overseas." 59

The above discussion is attuned to the North Pacific. Different scenarios and sensibilities, both empirical and conceptual, would no doubt present themselves if Banks were to be traced, in the manner undertaken here, to other fringes of his global operations and looked at from there. But similar questions about the local and global, 
and centres and margins - and the world interior of capital -- would surely enter the scene too.

\section{Bibliography}

Anderson, Ben, Kearnes, Matthew, McFarlane, Colin, and Swanton, Dan. 'Assemblages and geography.' Dialogues in Human Geography 2 (2012): 171-189.

BBC. Taboo 2017. https://www.bbc.co.uk/programmes/b088s45m

Beaglehole, J.C., The Journals of Captain Cook on his voyages of discovery, vol. 3: The voyage of the Resolution and Discovery, 1776-1780. Cambridge: Cambridge University Press/Hakluyt Society, 1967.

Belyea, Barbara. 'Aita-Aita Meares: The historian as archivist.' Unpublished ms.

Berg, Maxime. 'Sea otter and iron: A global microhistory of value and exchange at Nootka Sound, 1774-1792. Past and Present 242 (2019) Supplement 14, 50-82.

Bligh, William. A voyage to the South Seas... in his majesty's ship the Bounty. London: G. Nicol, 1792.

Bowen, H.V. 'British conceptions of global empire, 1756-83.' The Journal of Imperial and Commonwealth History, vol. 26 (1998): 1-27.

Carlson, Jon D. 'The "sea otter man" empires: The Pacific fur trade, incorporation and the zone of ignorance.' Journal of World-Systems Research 8 (2002): 390-442.

Carter, H.B. Sir Joseph Banks. London: British Museum, 1988.

Chambers, Neil, ed., The Indian and Pacific Correspondence of Sir Joseph Banks, 1768-1820, vol 2 Letters 1783-1789. London: Pickering \& Chatto, 2009.

Chambers, Neil, ed., The Indian and Pacific Correspondence of Sir Joseph Banks, 1768-1820, vol 3 Letters 1789-1792. London: Pickering \& Chatto, 2010.

Chambers, Neil, ed., The Indian and Pacific Correspondence, 1768-1820, vol. 4 Letters 17921798. London: Pickering \& Chatto, 2011.

Chambers, Neil, ed. The scientific correspondence of Sir Joseph Banks, 1765-1820, vol. 3 The middle period, 1785-1799. London: Routledge, 2007.

Clayton, Daniel W. Islands of truth: The imperial fashioning of Vancouver Island. Vancouver: UBC Press, 2000.

Cozens, Kenneth. 'East London merchant networks in Asia: the Fitzhugh's, 1750-1800, East India Company Agents in Macao.' Greenwich Maritime Institute, University of Greenwich. https://gre.academia.edu/KennethCozens 
Dorr, Ebenezer and sons. Ship. Hancock. Log book. University of British Columbia Archives and Special Collections Division.

Fichter, James R. So great a proffit: How the East Indies transformed Anglo-American capitalism. Cambridge MA: Harvard University Press, 2010.

Fisher, Robin, Contact and conflict: Indian-European relation in British Columbia, 1774-1890. Vancouver: UBC Press, 1977.

Fisher, Robin, and Bumsted, J.M., eds., An account of a voyage to the north west coast of America in 1785 and 1786 by Alexander Walker. Seattle: University of Washington Press, 1982.

Galois, Robert. A voyage to the north west side of America: The journals of James Colnett, 178689. Vancouver: UBC Press, 2004.

Gascoigne, John. 'Joseph Banks, mapping and the geographies of natural knowledge.' In Miles Ogborn and Charles W.J. Withers, eds., Georgian geographies: Essays on space, place and landscape in the eighteenth century. Manchester: Manchester University Press, 2004, 151-154.

Gascoigne, John. Science in the service of empire: Joseph Banks, the British state and the uses of science in the age of revolution. Cambridge: Cambridge University Press, 1998.

Gibson, James R. Otter skins, Boston ships and China goods: The maritime fur trade of the northwest coast, 1785-1841. Kingston: McGill Queen's, 1992.

Gough, Barry. Introduction. In Andrew David, ed., William Robert Broughton's voyage of discovery to the North Pacific 1795-1798. London: Hakluyt Society, 2010, xxi-1x.

Gray, Edward G. The making of John Ledyard: Empire and ambition in the life of an early American traveller. New Haven: Yale University Press, 2007.

Harlow, Vincent. The founding of the second British Empire, 1763-1793 2 vols. London: Longmans, Green and Co., 1952 and 1964.

Hoover, Alan L., ed. Nuu-chah-nulth voices, histories, objects and journeys. Victoria: Royal British Columbia Museum, 2000.

Hoppit, Julian. 'Sir Joseph Banks's provincial turn.' The Historical Journal 61 (2018): 403429.

Howay, F.W. 'Early days of the maritime fur-trade on the Northwest Coast.' Canadian Historical Review 4 (1923): 287-309.

Howay, F.W. 'Four letters from Richard Cadman Etches to Sir Joseph Banks, 1788-92.' British Columbia Historical Quarterly 6 (1942): 125-39. 
Howay, F.W., ed., Voyages of the Columbia to the northwest coast 1787-1790 and 1790-1793. Orig. pub. 1941. Portland: Oregon Historical Society Imprint, 1990.

Igler, David. The great ocean: Pacific worlds from Captain Cook to the gold rush. Oxford: Oxford University Press, 2013.

Jewitt, John. The adventures and sufferings of John Jewitt, captive of Maquinna. Annonated by Hilary Stewart. Orig. Pub. 1815. Vancouver: Douglas \& McIntyre, 1987.

King, Robert J. '"The long wish'd for object" - Opening the trade to Japan, 1785-1795.' The Northern Mariner 20 (2010): 1-34.

Klein, Lawrence. 'Politeness and politics of the interpretation of the British eighteenth century.' The Historical Journal 45 (2000): 869-898

Lamb, W. Kaye. The voyage of George Vancouver 1791-1795, 4 volumes and atlas. London: Hakluyt Society, 1984.

Lamb, W. Kaye, and Bartoli, Tomás, 'James Hanna and John Henry Cox: The first maritime fur trader and his sponsor,' BC Studies 84 (1989): 3-36.

Lang, William, and Walker, James eds. Explorers of the maritime Pacific Northwest. Seattle: ABC-Clio, 2016.

Livingstone, David N. Putting science in its place: Geographies of scientific knowledge. Chicago: University of Chicago Press.

Mackay, David. 'Myth, science, and experience in the British construction of the Pacific.' In Alex Calder, Jonathan Lamb, and Bridget Orr, Voyages and beaches: Pacific encounters, 1769-1840 Honolulu: University of Hawai'i Press, 1999, pp. 100-113

Mackay, David. In the wake of Cook: Exploration, science and empire, 1780-1801. New York: St Martin's Press, 1985.

Mapp, Paul. The elusive west and the contest for empire, 1713-1763. Chapel Hill: University of North Carolina Press, 2012.

Marx, Karl. Grundrisse: Foundations of the critique of political economy (rough draft). Trans. Martin Nicolaus. Harmondsworth: Penguin, 1973.

Marx, Karl. Capital: A critique of political economy, vol. 3. Penguin Classics edition. London: Penguin, 1992.

Matsuda, Matt K. Pacific worlds. Cambridge: Cambridge University Press, 2012.

Meares, John. Voyages made in the years 1788 and 1789, from China to the north west coast of America. London: Logographic Press, 1790. 
Menzies, Archibald. 'A description of the anatomy of the sea otter.' Royal Society, Philosophical Transactions (1796): A2-12.

Miller, David Philip. 'Joseph Banks, empire, and "centres of calculation" in late Hanoverian London.' In David Philip Miller and Peter Hanns Reill, eds., Visions of empire: Voyages, botany and representations of nature. Cambridge: Cambridge University Press, 1996, 21-37.

Moonen, Tim. 'The modern arts of world-making.' LA Review of Books. https://lareviewofbooks.org/article/modern-arts-world-making/

Newcombe, C.F., ed. Menzies' journal of Vancouver's voyage April to October 1792. Victoria: Archives of British Columbia Memoir no. 4, 1923.

Rigby, Nigel. "'Men of Captain Cook": Pacific voyages 1785-1803'. In John McAleer and Nigel Rigby, Captain Cook and the Pacific: Art, exploration, and empire. Yale: Yale University Press/Greenwich Maritime Museum, 2017, 169-200.

Rodger, N.A.M. The insatiable earl: A life of John Montagu, fourth Earl of Sandwich, 17181792 (London: Harper Collins, 1993), 204-208.

Ronda, James P. Finding the west: Explorations with Lewis and Clark. Albuquerque: University of New Mexico Press, 2001).

Rupke, Nicolaas. 'Afterword: Putting the geography of science in its place.' In David N. Livingstone and Charles W.J. Withers, eds., Geographies of nineteenth-century science. Chicago and London: University of Chicago Press, 2011, 439-450.

Said, Edward W. Culture and imperialism. New York: Alfred Knopf, 1993.

Secord, James A. Visions of science: Books and readers at the dawn of the Victorian age. Oxford: Oxford University Press, 2014.

Sloterdijk, Peter. In the world interior of capital trans: Towards a philosophical theory of globalization. Wieland Hoban trans. Cambridge: Polity Press, 2013.

Strange, James. James Strange's journal and narrative of the commercial expedition from Bombay to the north-west coast of America. Madras: Government Press, 1929.

Tovell, Freeman M., Inglis, Robin, and Engstrand, Iris H.W., eds., Voyage to the northwest coast of America, 1792: Juan Francisco de la Bodega y Quadra and the Nootka Sound controversy. Norman OK: The Arthur H. Clark Company, 2012

Vries, Jan de. 'Playing with scales: The global and the micro, the macro and the nano.' Past and Present 242 (2019): 23-36.

Werrett, Simon. 'Introduction: Rethinking Joseph Banks.' Notes and Records 73 (2019): 425-429 
Williams, Glyndwr. "'The common centre of we discoverers": Sir Joseph Banks, exploration and empire in the late eighteenth century.' In R.E.R Banks, B. Elliott, J.G. Hawkes, D. King-Hele and G.L. Lucas, eds., Sir Joseph Banks: A global perspective. Kew: Royal Botanical Gardens, 1994, 177-191.

Zilberstein, Anya. 'Objects of distant exchange: The northwest coast, early America, and the global imagination, The William and Mary Quarterly, Third Series 64 (2007): 591620.

\section{Notes}

${ }^{1}$ See, Fisher, Contact and conflict; Clayton, Islands of truth, Hoover, ed., Nuu-chah-nulth voices; Igler, The Great Ocean, Ch. 3; Berg, 'Sea otters and iron'; Carlson, 'The "sea otter man" empires'; R.E.R Banks et al., Sir Joseph Banks; and BBC, Taboo.

${ }^{2}$ Matsuda, Pacific worlds, 187.

${ }^{3}$ The paper works chiefly with Sloterdijk's In the world interior of capital. For a good overview of Stolerdijk's book, and its place in his wider philosophical project, see Moonen, 'The modern arts of world-making' (accessed July 16, 2017).

${ }^{4}$ The manuscript chart is included in J.C. Beaglehole's Journals of Captain Cook, 3, plate 38

${ }^{5}$ Lamb and Bartoli, 'James Hanna and John Henry Cox,'.

${ }^{6}$ F.W. Howay, 'Early days of the maritime fur-trade,' 42-43.

${ }^{7}$ Howay, Voyages of the Columbia, 345-50

${ }^{8}$ Chambers ed., Indian and Pacific Correspondence of Sir Joseph Banks, vol. 2, 66 From Richard Cadman Etches 14 March 1785; and 229, 230, 232, 235.

${ }^{9}$ These figures are based on Bob Galois's synthesis of Cadman correspondence and financial records, in Galois, ed., A voyage to the north west side of America, Table 1, 18, also see 6-8, 276-84; The National Archives, Currency Converter, http://www.nationalarchives.gov.uk/currency-converter/ (accessed Jan. 5, 2019).

Shortly thereafter, in December 1787, William Bligh (master of the Resolution on Cook's third voyage) sailed for Tahiti to take breadfruit plants to the West Indies to feed the slave population; and in January 1788 eleven British ships arrived at Botany Bay with a cargo of convicts to establish a colony in Australia. Etches's venture constituted a third leg of this British project, and they were all attempts to "derive benefit" from Cook's "distant discoveries", as Bligh put it, Voyage to the South Seas, 7. Historians have debated whether (in the memorable phrase of Vincent Harlow) these ventures amounted to a 'swing to the East' in British imperial strategy in the wake of the Seven Years War (17561763). Harlow, Founding of the second British Empire, I, Ch. 3; and see Bowen, 'British conceptions of global empire, 1756-83'; and Nigel Rigby, '"Men of Captain Cook", ' on how these post-Cook voyages can be traced through the collections of the Greenwich Maritime Museum, London.

${ }^{10}$ Gibson, Otter skins, Boston ships, 58.

${ }^{11}$ Marx, Capital, 3, 379

${ }^{12}$ Walker, Account of a voyage, 56, 62.

${ }^{13}$ Strange, Journal and narrative, 2-3, 26. Mackay, 'A presiding genius of exploration,' 35.

${ }^{14}$ Mackay, 'Myth science and experience,' 100-101. 
${ }^{15}$ Klein, 'Politeness.'

${ }^{16}$ Meares, Voyages, 142.

${ }^{17}$ Cited in Gough, Introduction, William Broughton's voyage of discovery, xxxix.

${ }^{18}$ Mapp, The elusive west, 432.

${ }^{19}$ The full story is told in Tovell, Inglis, and Engstrand, Voyage to the Northwest Coast.

${ }^{20}$ On this battle, see Clayton, Islands of Truth, Part 3.

${ }^{21}$ Jewitt, Adventures and sufferings, 30

${ }^{22}$ See Clayton, Islands of truth, Part 2, for an extended discussion.

${ }^{23}$ Hoppit, 'Banks's provincial turn,' 403-404.

${ }^{24}$ Hoppit, 'Banks's provincial turn,' 406.

${ }^{25}$ Hoppit, 'Banks's provincial turn,' 407.

${ }^{26}$ And one wonders about whether such an orientation might fuel, or by fed by, the current resurgence in nationalist, separatist, identarian and isolationist sentiment across the world.

${ }^{27}$ Jan de Vries, 'Playing with scales'

${ }^{28}$ See, especially, Livingstone, Putting science in its place.

${ }^{29}$ Werritt, Introduction, 426. See Goodman's paper, this issue.

${ }^{30}$ Rupke, 'Afterword,' 450.

${ }^{31}$ Said, Culture and imperialism, 50.

${ }^{32}$ Marx, Grundrisse, 856.

${ }^{33}$ Dorr, Hancock, Log book. f. 38.

${ }^{34}$ Cited in Sloterdijk, In the world interior of capital, 198.

${ }^{35}$ Sloterdijk, In the world interior of capital, 169-72

${ }^{36}$ Sloterdijk, In the world interior of capital, 172.

${ }^{37}$ See Williams, '"The common centre of we discoverers,' and Miller, 'Joseph Banks, empire, and "centres of calculation" in late Hanoverian London.'

${ }^{38}$ I worked on Banks's papers and the Dawson Turner copies in the British Museum in the early 1990s, before Neil Chambers's project to collate his Indian and Pacific correspondence had come to fruition. Chambers is deferred to here. He has pulled together most of the material pertaining to the Northwest Coast, which was previously scattered in archives in British Columbia, California, Hawai'i, New South Wales and Scotland, as well as London, although the 1920s British Columbia historians F.W. Howay and C.F. Newcombe collated a good portion of it. Only dribs and drabs of new Banks Northwest Coast material has come to light in recent decades, not least in the work of Kenneth Cozens, Bob Galois, and Robert King. For overviews of Banks' connections to the North Pacific also see Gascoigne, Science in the service of empire, and Rodger, The insatiable earl, 204-208.

${ }^{39}$ Mapp, The elusive west, Fichter, So great a profit.

${ }^{40}$ Sloterdijk, In the world interior of capital, 63.

${ }^{41}$ Sloterdijk, In the world interior of capital, 133. The allusion, of course, is the work of maritime historians Marcus Rediker and Peter Linebaugh.

${ }^{42}$ See Clayton, Islands of truth, Ch.11.

${ }^{43}$ Chambers ed., Indian and Pacific Correspondence of Sir Joseph Banks, 3, doc. 139 From Banks 22 February 1791.

${ }^{44}$ See Chambers, ed., Indian and Pacific Correspondence of Sir Joseph Banks, vol. 4, docs. 85, and 156, 187, 188, 311; and vol. 4, docs. 13, 20, 57, 96, 101, 116, 140, 149, 171, 178, 195, 196, 198, 200, 203, 204, 224, 278, 309; Lamb, The voyage of George Vancouver, vol. IV, Appendix 5, Selections from Menzies' correspondence with Banks, 1614-1632; Newcombe, ed., Menzies' journal of Vancouver's voyage. 
${ }^{45}$ Sloterdijk, In the world interior of capital, 132

${ }^{46}$ Menzies, 'Description of the anatomy of the sea otter.'

${ }^{47}$ Chambers, ed., Indian and Pacific correspondence, vol. 2, doc. 93 From Richard Cadman Etches 29 September 1786.

${ }^{48}$ Mackay, In the wake of Cook, 61; King, "'The long wish'd for object"'. Also see Carter, Sir Joseph Banks. Banks published Engelbert Kaempfer's Japanese botanical drawings (held in the British Museum), Icones selectae Plantarum quae in Japonia collegit et delineavit Engelbertus Kaempfer, in 1791

${ }^{49}$ Howay, 'Four letters from Richard Cadman Etches to Sir Joseph Banks, 1788-92.'

${ }^{50}$ Zilberstein, 'Objects of distant exchange,' 620

${ }^{51}$ Zilberstein, 'Objects of distant exchange,' 620; also see Igler, The great ocean; Hoover, ed., Nuu-chah-nulth voices, histories, objects and journeys.

${ }^{52}$ Chambers, ed., Scientific correspondence of Sir Joseph Banks, 1765-1820, vol. 3, doc. 877 From Thomas Drylander 9 October 1788.

${ }^{53}$ Chambers, ed., Indian and Pacific correspondence, vol. 3, doc. 311 Nootka Sound 26 September 1792.

${ }^{54}$ To add to the intrigue, still the best paper on this question is an unpublished paper by Barbara Belyea, "Aita-Aita Meares: The historian as archivist." A good selection of documents pertaining to Dixon, Meares, Etches, Colnett and the Nootka Crisis are reproduced and annotated in William Lang and James Walker eds., Explorers of the maritime Pacific Northwest.

${ }^{55}$ Gascoigne, 'Joseph Banks, mapping and the geographies of natural knowledge,' 152.

${ }^{56}$ Secord, Visions of science, 57.

${ }^{57}$ Ronda, Finding the west, 23.

${ }^{58}$ For a theoretical overview of geographers's fascination with assemblages, see Anderson, et. al. 'On assemblages and geography,'

${ }^{59}$ Sloterdijk, In the world interior of capital, 78-79. 